Health \& Medicine | David W. Green

\section{A paradigm shift for fluid management in surgery}

\begin{tabular}{|c|c|c|}
\hline $\begin{array}{l}\text { Advances in modern surgery } \\
\text { have been dependent upon } \\
\text { advances in anaesthetic } \\
\text { management. However, } \\
\text { anaesthesia can have } \\
\text { detrimental effects, as it is } \\
\text { usually associated with reduced } \\
\text { blood pressure, cardiac } \\
\text { output and oxygen delivery. } \\
\text { To counteract these changes, } \\
\text { large quantities of intravenous } \\
\text { fluids have been administered } \\
\text { both during and often for many } \\
\text { hours post-surgery. This was in } \\
\text { an attempt to maintain blood } \\
\text { pressure by compensating } \\
\text { for the so-called "third space } \\
\text { loss" from the circulation into } \\
\text { the interstitial space. However, } \\
\text { this "third space" loss has now } \\
\text { been deemed erroneous and } \\
\text { surgeons and anaesthetists } \\
\text { have now become concerned } \\
\text { about the side effects of this } \\
\text { fluid overload. Drs Green } \\
\text { and O'Brien have looked at } \\
\text { how the use of intraoperative } \\
\text { monitoring and management } \\
\text { protocols can mitigate some } \\
\text { of the deleterious effects } \\
\text { of anaesthesia on the } \\
\text { circulation without the need } \\
\text { for excessive fluids. This has } \\
\text { resulted in a fundamental } \\
\text { and paradigm shift in } \\
\text { our understanding of the } \\
\text { physiology of the circulation } \\
\text { and blood pressure control. }\end{array}$ & $\begin{array}{l}\text { he intricate nature of modern } \\
\text { surgery stands diametrically } \\
\text { opposed to the rapid limb } \\
\text { amputation in pre-modern surgery. } \\
\text { Surgery has become much safer through } \\
\text { many changes, most notably anaesthetic } \\
\text { management. Although this has enabled } \\
\text { much sicker patients to be operated } \\
\text { upon and for much longer durations } \\
\text { than was previously possible, modern } \\
\text { surgery is also unfortunately associated } \\
\text { with high morbidity and mortality. } \\
\text { One important feature of operative } \\
\text { management, closely associated with } \\
\text { anaesthesia, is fluid management. } \\
\text { FLUID MANAGEMENT AND } \\
\text { "THIRD SPACE" FLUID LOSS } \\
\text { Fluid management involves the } \\
\text { administration of intravenous (IV) fluid }\end{array}$ & $\begin{array}{l}\text { therapy by anaesthetists throughout } \\
\text { surgery. IV fluid is often given just } \\
\text { before the operation, to prepare the } \\
\text { patient's body for surgery, during } \\
\text { surgery to maintain blood pressure and } \\
\text { oxygen delivery, and after surgery to } \\
\text { assist with the recovery process. } \\
\text { Whilst anaesthesia is essential for keeping } \\
\text { the patient tunconscious and pain free, it } \\
\text { also creates other problems. Anaesthesia } \\
\text { depresses not only the central nervous } \\
\text { system to render the patient unconscious } \\
\text { but also the cardiovascular system. The } \\
\text { latter effect is to reduce blood pressure } \\
\text { and cardiac output, which leads to lower } \\
\text { levels of tissue oxygen delivery during } \\
\text { surgery, thus creating an oxygen debt } \\
\text { which can be substantial depending on } \\
\text { the extent and duration of surgery and } \\
\text { anaesthesia. Unsurprisingly, depriving } \\
\text { your cells of oxygen can inevitably lead } \\
\text { to tissue damage, organ ndysfunction and } \\
\text { failure if this oxygen debt is not quickly } \\
\text { repaid. But what was the physiological } \\
\text { mechanisms behind the drop in } \\
\text { blood pressure? } \\
\text { Sixty years ago, a pioneering study } \\
\text { described the concept of the "third } \\
\text { space fluid loss", in which patients } \\
\text { could accumulate significant } \\
\text { amounts of "internal" fluid loss } \\
\text { during surgery. The study suggested } \\
\text { that potentially large volumes of } \\
\text { fluid flowed from the functional } \\
\text { circulation into another part of the } \\
\text { body - the interstitial space, which is the } \\
\text { gap between cells in tissues throughout } \\
\text { the body. This occult "internal" fluid } \\
\text { movement and loss from the circulation } \\
\text { was identified as the causal link for the } \\
\text { reduction in blood pressure as it reduced }\end{array}$ \\
\hline
\end{tabular}

the volume of the functional circulation on which blood pressure, cardac
oxygen delivery depend.

This "new" model appeared to provide a simple and effective solution: replace the fluid leaking out of the patient's blood vessels with a fluid solution that contains similar electrolytes found in normal body fluid. Any fluid lost from the blood vessels would be replaced by be maintained at baseline pre-surgery levels, allowing the cardiovascular system to deliver adequate supplies of oxygen to the tissues and reduce complications. It was a seemingly simple solution to a daunting prob a potentially life-saving method.

A SIMPLE (IV-BASED) SOLUTION? The concept of "third space" fluid loss led, both literally and figuratively, to a new practice of "high volume IV therapy" during surgery. However, often the amounts of fluid and electrolytes administered were excessive as compared to normal daily requirements.

Surgeons and anaesthetists thus began to seriously debate the topic of perioperative fluid

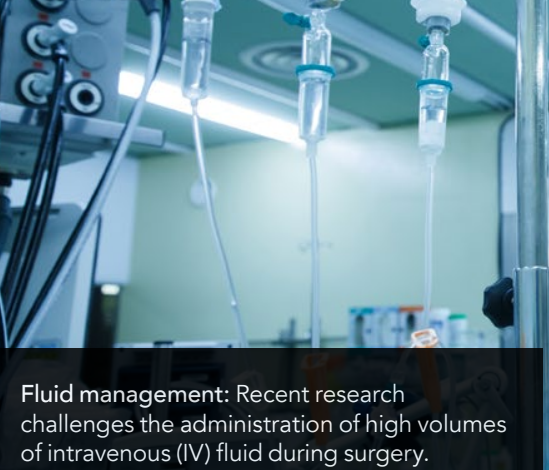

does not undergo any "third space" loss during a surgical procedure. The foundations upon which high volume disuid therapy were built have now disappeared and the rationale for this been thrown into question.

Unfortunately, the excess fluid isn't just a waste of perfectly good electrolyte solution. In fact, research has shown that "third space" fluid loss can actually be created by a "liberal" - a i.e. a large volume - of fluid treatment. Researchers investigated the impact of Within a three and a half hour operation, how much IV fluid a patient can be given the sodium they problematic in elderly receive. Should Would normally require in six days. to the physiological administration of fluid, or have we gone fluid management on the endothelia too far and perhaps a "restrictive" volume of fluids is more appropriate?

However, recent research analysing the phenomenon of "third space" loss has found it to be a less common occurrence and some of the science behind the calculation of "third space" loss was flawed. In fact, recent research suggests that the average patien

glycocalyx, which is a layer of carbohydrates that lines the cell walls twist their research suggested that the glycocalyx, which creates leakage into the interstitial space.

It's easy to see why high-volume fluid treatment could be considered

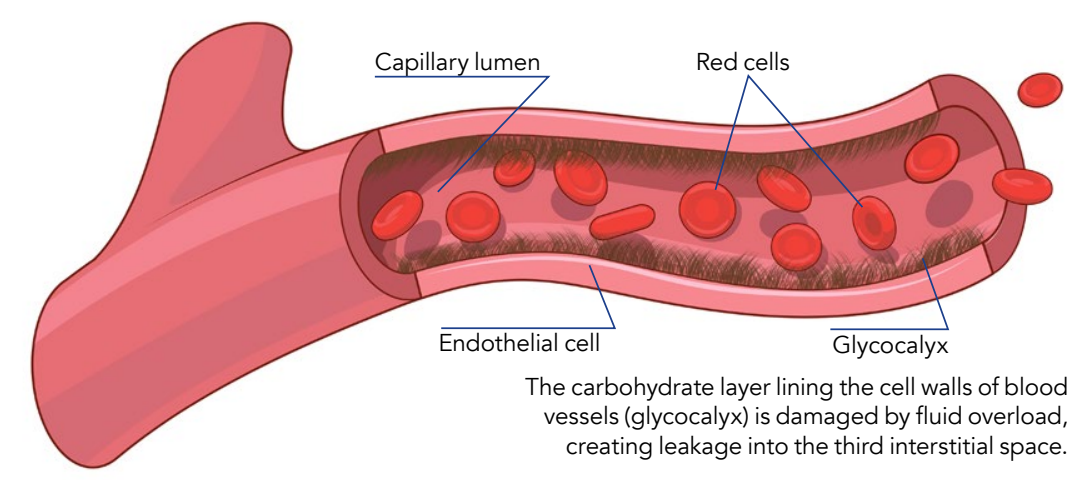
on, causing acidosis. patients, who due

dangerous. It's a procedure in which you pump an abnormal volume of liquid into a person; the fluid includes ions such standard IV solution may contain 2 days' worth of ions. Within a three and a half hour surgical procedure, a patient can be require in six days. into the patient during surgery may lead to heart, lung, and intestinal problems in the post-operative problems in the post-operative effects of ageing are at higher risk of complications. They so undergo surgery in proportion to than younger people.

A NEW SOLUTION USING LESS SOLUTION Dr David Green, an anaesthetist based at King's College Hospital, began looking for a new solution to this vexing problem with his colleagues, one which promises to address the problems of reduced blood pressure and oxygen delivery and the subsequent tissue effects of fluid overload. This involves both a practical change in using different treatments and utilising new equipment, and a broader shift in the theoretical framework employed.
A "liberal" volume of IV fluid injected

Intraoperative monitoring (monitoring 


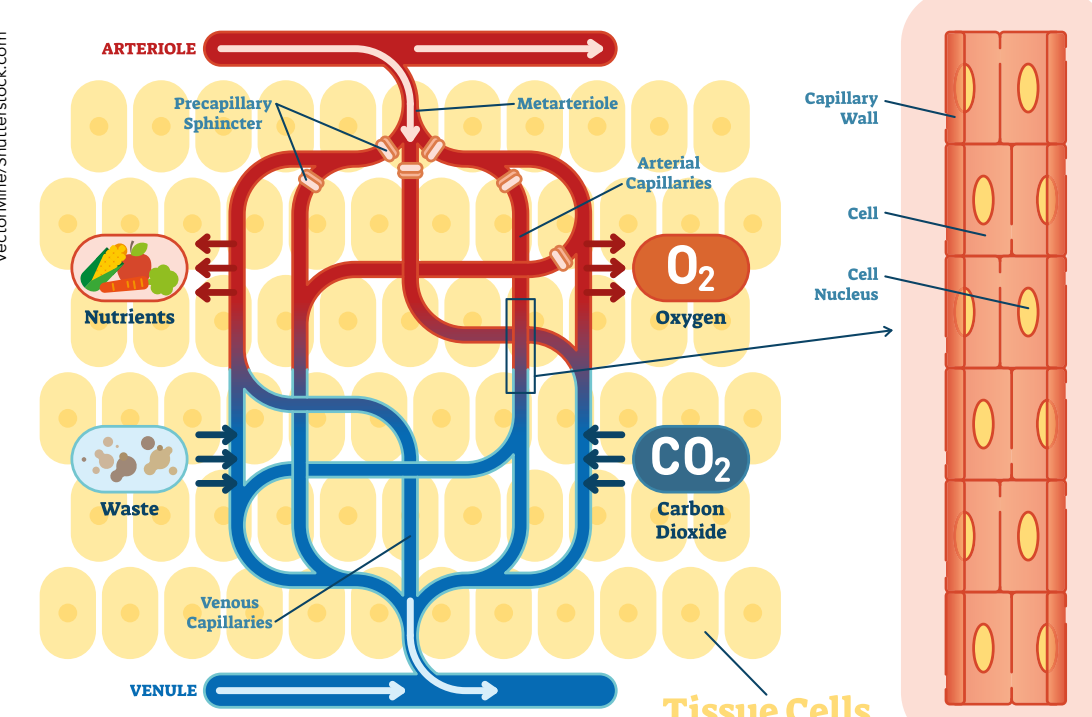

The venous circulation. It is now appreciated that the fall in blood pressure associated with
anaesthesia isn't dee to the flwial anaesthesia on the venous cliculation.

feature of this new approach. Recent advances in medical technology have monitors which can now give precise measurements of the patient's body whilst being almost completely noninvasive. One of Dr Green's papers explores this monitoring in great depth, arguing for a "multimodal" monitoring approach (MMM) for highrisk surgery patients. This includes measuring the blood flow, the "depth" of the anaesthetic induced shutdown of your central nervous system, and how much oxygen the brain and the body's tissues receive with nearinfrared technology. Whilst the results need to be corroborated with larger randomised clinical trials (RCTs), it does show promise for the use of monitoring technologies.

Practically, it involves changing the way This includes a more carefully titrated approach to anaesthesia. It is facilitated by the new monitoring equipment, thus allowing better assessment of the effects of anaesthesia on the individual patient. This helps to maintain blood pressure, cardiac output and oxygen delivery. The technique also includes the infusion of small doses of vasoactive drugs such phenylephrine, which help to stabilise blood pressure and maintain cardiac output and oxygen delivery witho requiring fluid overload.

As the effects of anaesthesia can now be measured during the operation, it's
possible to micromanage the effects of IV were able to devise this management solution when they realised that the an hesthesia isn't due to the fluid lost to the interstitial space. Rather it's caused by specific effects of anaesthesia on the venous circulation. Anaesthesia dilates the veins and this increased venous capacity leads to blood flowing from the arterial circulation in an attempt to fill this now enlarged space with an inevitable fall in blood pressure as a result.

The previous assumption assumed it was predominantly dilation of the arterial vessels and not the venous circulation which led to reduced blood pressure and led to tissues not receiving the blood (and oxygen) they need. Ofsetting this "venodilation "with low doses of vasoconstrictive drugs acting phenylephrine can help to restore and maintain blood pressure while maintaining cardiac output and oxygen delivery lin contrast, vasoconstrictive drugs which at higher doses predominantly cause tightening or constriction of the arterial circulation will also restore blood pressure $\begin{array}{ll}\text { shis reflects a theoretical paradigm } & \text { circulation will also restore blood pressure } \\ \text { shift win our understanding of blood } & \text { but their use also runs the risk of reducing } \\ \text { circulation both during surgery and } & \text { tissue blood flow and oxygen delivery, } \\ \text { anaesthesia. Dr Green and his colleagues } & \text { as the heart has to overcome a higher }\end{array}$ $\begin{array}{ll}\text { shift within our understanding of blood } & \text { but their use also runs the risk of reduc } \\ \text { circulation both during surgery and } & \text { tissue blood flow and oxygen delivery, } \\ \text { anaesthesia. Dr Green and his colleagues } & \text { as the heart has to overcome a higher }\end{array}$ Dr Green and his collea

This reflects a theoretical paradigm shift within our understanding of blood circulation within surgery, and general physiology.

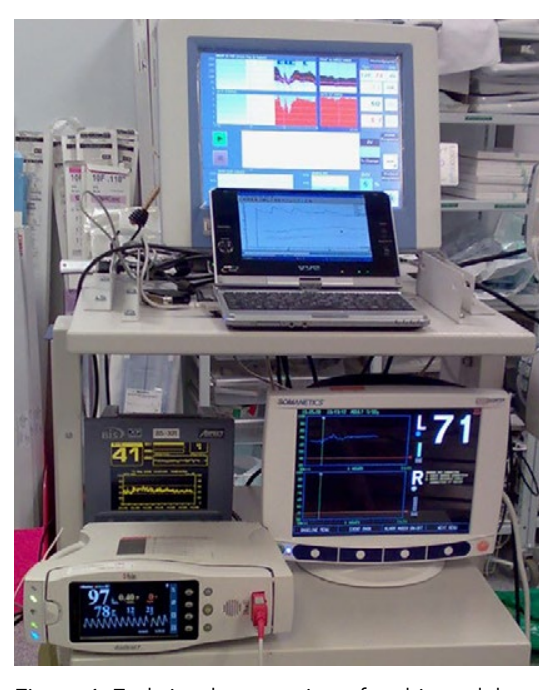

Figure 1. Early implementatition of multi-modal
monitoring (MMM) in 2008 at Kin's College Hospital. A complex setup! MMM has now been
greatly simplified in 2021 (see Figure 2a and $2 b$ ) This is the opposite of what is needed! LDCO Rapid, LDCO PLC, UK, now part of Masimo Corporation, USA) is needed to make sure that cardiac output is not adversely affected by the use of powerfu vasoactive drugs.

This research and the results obtained helped to create a new model of how blood pressure is controlled not only during anaesthesia but also generally. This reflects a broader paradigm shift in physiology as researchers have begun to look much more closely at the mpontance of the venous circlation. It's constantly undergoes. output (such as dering from uniac

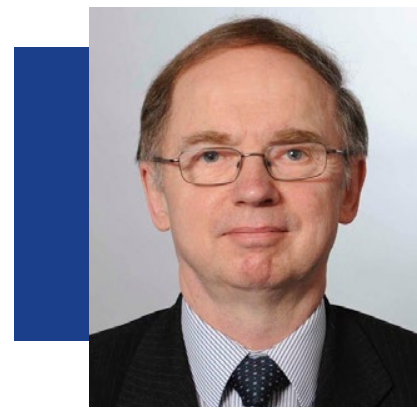

\section{Behind the Research}

\section{Dr David W. Green MB BS FRCA MBA}

Research Objectives

Dr Green's research interests include the investigation of circulatory physiology and patho-physiology during

\section{Detail}

Dr David Green MB BS FRCA MBA is an honorary Senior at King's College Hospital and King's Health Partners in

Collaborators

Dr Terry O'Brien BSc (Hons), PhD, Founder Chief Executive - fficer of LIDCO Limited, London, UK and formerly

Thomas' Hospital, GKT School of Medical Education.

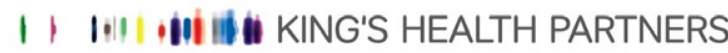
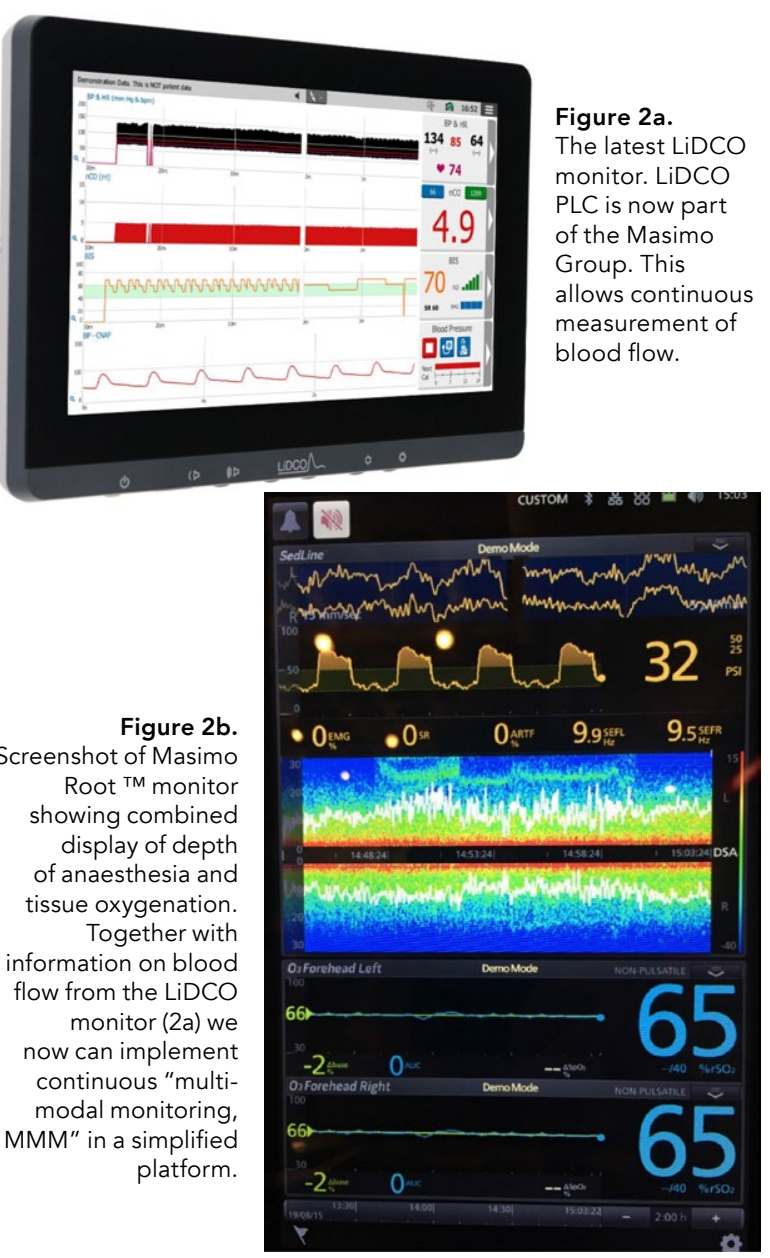

\section{References}

Wolff CB, Green DW, Paton JFR, \& Collier DJ. (2020). A New odel of the Circulation with Important Clinical Implications. Am J Surg Clin Case Rep. 2(1).
http://dx.doi.org/10.47829/AJSCCR.2020.2601

Green DW, \& O'Brien T. (2016). Restoration to normal physiology without the use of excessive fluids. British Journa

Green DW, Bidd H, \& Rashid H. (2014). Multimodal risk patients undergoing major peripheral vascular surgery. https://doio.org/10.1016/i.jisu.2013.12.016 Wolff CB, \& Green DW. (2014). Clarification of the circulatory patho-physiology of anaesthesia - implications for high-risk

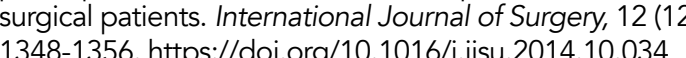
Bidd H, Tan A, \& Green DW. (2013). Using bispectral index and cerebral oximetry to guide hemodynamic therapy in highrisk surgical patients. Perioperative Medint
https://doi.org//10.1186/2047-0525-2-11

\section{Personal Response}

In terms of a shift towards analysing venous circulation and venodilation in blood circulation, what impacts

II Understanding the role of the venous circulation and in anaesthesia but also in medicine generally. The crucial dependence of blood pressure on the ratio of volume of blood in the arterial to venous circulation has not conducted on evaluating the role of the venous circulation in patients with high blood pressure and the possibilitities

How practical are your new recommendations for piect of monitoring technology, can institutions like the NHS feasibly afford to implement your suggestions?

All the technology mentioned, such as evaluating depth of anaesthesia, tissue oxygenation and blood flow (the three main components of multimodal monitoring, MMMM) are all
available and now relatively inexpensive The savings and patient benefits accrued due to reduced complications and mortality which I believe are possible if this technology is used correctly are enormous. In $2021 \mathrm{MMM}$ has been
facilitated by the integration of monitoring technologies, a shown in Figure $2 a$ and $2 b$. 